\title{
Role of Calcium in Phosphatidylserine Externalisation in Red Blood Cells from Sickle Cell Patients
}

\author{
Erwin Weiss, ${ }^{1}$ David Charles Rees, ${ }^{2}$ and John Stanley Gibson ${ }^{1}$ \\ ${ }^{1}$ Department of Veterinary Medicine, University of Cambridge, Madingley Road, Cambridge CB3 OES, UK \\ ${ }^{2}$ Department of Molecular Haematology, King's College School of Medicine, London SE5 9RS, UK
}

Correspondence should be addressed to John Stanley Gibson, jsg1001@cam.ac.uk

Received 13 July 2010; Accepted 23 August 2010

Academic Editor: Ferreira Costa

Copyright ( $) 2011$ Erwin Weiss et al. This is an open access article distributed under the Creative Commons Attribution License, which permits unrestricted use, distribution, and reproduction in any medium, provided the original work is properly cited.

\begin{abstract}
Phosphatidylserine exposure occurs in red blood cells (RBCs) from sickle cell disease (SCD) patients and is increased by deoxygenation. The mechanisms responsible remain unclear. RBCs from SCD patients also have elevated cation permeability, and, in particular, a deoxygenation-induced cation conductance which mediates $\mathrm{Ca}^{2+}$ entry, providing an obvious link with phosphatidylserine exposure. The role of $\mathrm{Ca}^{2+}$ was investigated using FITC-labelled annexin. Results confirmed high phosphatidylserine exposure in RBCs from SCD patients increasing upon deoxygenation. When deoxygenated, phosphatidylserine exposure was further elevated as extracellular $\left[\mathrm{Ca}^{2+}\right]$ was increased. This effect was inhibited by dipyridamole, intracellular $\mathrm{Ca}^{2+}$ chelation, and Gardos channel inhibition. Phosphatidylserine exposure was reduced in high $\mathrm{K}^{+}$saline. $\mathrm{Ca}^{2+}$ levels required to elicit phosphatidylserine exposure were in the low micromolar range. Findings are consistent with $\mathrm{Ca}^{2+}$ entry through the deoxygenation-induced pathway $\left(\mathrm{P}_{\text {sickle }}\right)$, activating the Gardos channel. $\left[\mathrm{Ca}^{2+}\right]$ required for phosphatidylserine scrambling are in the range achievable in vivo.
\end{abstract}

\section{Introduction}

Patients with sickle cell disease (SCD) display a range of symptoms which include chronic anemia together with ischemic pain and organ damage [1]. The underlying cause is the presence in patients' red blood cells (RBCs) of the abnormal hemoglobin, HbS [2]. HbS polymerises into rigid rods on deoxygenation, changing $\mathrm{RBC}$ shape from biconcave disc into the characteristic sickle appearance [3]. RBC membrane permeability is markedly abnormal [4] whilst $\mathrm{HbS}$ is also unstable, representing an oxidative threat [5]. Altered behaviour of these HbS-containing RBCs (here termed $\mathrm{HbS}$ cells), other circulating cells, and the endothelium combine to reduce RBC lifespan (hence the anemia) and also result in microvascular occlusion (hence the ischemia) [6]. Although the exact pathogenesis remains unclear, an important feature is considered to be increased exposure of phosphatidylserine (PS) on the outer bilayer of the RBC membrane [7-10]. Externalised PS is prothrombotic, and also provides a potential adhesion site for both macrophages and activated endothelial cells, contributing to both reduced $\mathrm{HbS}$ cell lifespan and vascular occlusion [11-13].
Two membrane phospholipid transporters represent the major determinants of PS exposure in RBCs: the ATPdependent aminophospholipid translocase (APLT or flippase) transports aminophospholipids (APs), including PS, from outer to inner leaflet, whilst the $\mathrm{Ca}^{2+}$-dependent scramblase moves APs rapidly in both directions thus disrupting phospholipid asymmetry [14]. In normal RBCs, PS is largely confined to inner leaflet, through the dominant action of the flippase whilst the scramblase remains quiescent. A small, but variable, proportion of $\mathrm{HbS}$ cells from sickle cell patients, however, show exposure of PS ranging from about $2-10 \%$ $[7,9,15,16]$. Both flippase inhibition and activation of the scramblase are probably involved [17]. Flippase inhibition could follow oxidative stress $[18,19]$, whilst scramblase activation could be caused by raised intracellular $\mathrm{Ca}^{2+}$ (e.g., $[19,20])$ or other stimuli (e.g., [21]). The exact mechanisms, however, remain uncertain.

It is also well established that deoxygenation of $\mathrm{HbS}$ in vitro results in increased PS exposure [22, 23] but, again, the mechanism is not clear. Possibilities include disruption of the spectrin cytoskeleton [24], ATP depletion [25], decrease in intracellular $\mathrm{Mg}^{2+}[26]$, and also a rise in intracellular $\mathrm{Ca}^{2+}$ 
$[20,26]$. In many reports concerning PS exposure, however, $\mathrm{Ca}^{2+}$ is not controlled or is present at unphysiological levels, making it difficult to assess its role definitively. In addition, whilst a more recent study correlated PS exposure in $\mathrm{HbS}$ cells with flippase inhibition, rather than elevation of intracellular $\mathrm{Ca}^{2+}$, the effects of deoxygenation were not determined [9].

Deoxygenation of $\mathrm{HbS}$ cells as well as causing $\mathrm{HbS}$ polymerisation and shape change, also activates a permeability pathway termed $\mathrm{P}_{\text {sickle }}[4,27] . \mathrm{P}_{\text {sickle }}$ is often described as a deoxygenation-induced cation conductance, apparently unique to HbS-containing red cells. A major importance of $\mathrm{P}_{\text {sickle }}$ is its permeability to $\mathrm{Ca}^{2+}[28,29]$. Although $\mathrm{Ca}^{2+}$ entry via this pathway represents an obvious link between $\mathrm{HbS}$ polymerisation and the deoxygenation-induced PS exposure, estimates suggest that the magnitude to which $\mathrm{Ca}^{2+}$ may be elevated is still relatively modest (around $100 \mathrm{nM}$ ) [29], and several orders of magnitude below that required for scramblase activation (around $100 \mu \mathrm{M}$ is usually cited $[20,30-32])$. The present work is aimed at assessing the role of $\mathrm{Ca}^{2+}$ in PS exposure in RBCs from sickle cell patients.

\section{Materials and Methods}

2.1. Blood. Anonymised, discarded, routine blood samples (taken into the anticoagulant EDTA) were collected from individuals homozygous for $\mathrm{HbS}$ (HbSS genotype, $n=$ 62) with approval from the local Ethics committee. After withdrawal, blood samples were kept refrigerated until used. (RBCs from HbSS individuals are here termed HbS cells).

2.2. Salines and Chemicals. HbS cells were washed into low (LK) or high potassium- (HK-) containing saline, comprising (in $\mathrm{mM}$ ) $\mathrm{NaCl} 140, \mathrm{KCl} 4$, glucose 5, HEPES 10 for $\mathrm{LK}$ saline, and $\mathrm{NaCl} 55, \mathrm{KCl} 90$, glucose 5 and HEPES 10 for $\mathrm{HK}$ saline, all $\mathrm{pH} 7.4$ at $37^{\circ} \mathrm{C}$, with different extracellular $\left[\mathrm{Ca}^{2+}\right] \mathrm{s}\left(\left[\mathrm{Ca}^{2+}\right]_{o} \mathrm{~s}\right)$ as indicated. When required, inhibitors (clotrimazole, DIDS, and dipyridamole) were added from stock solutions in DMSO. In these experiments, DMSO (final concentration $0.5 \%$ ) was also added to controls. To investigate the effect of $\mathrm{Ca}^{2+}$ chelation, MAPTAM $(5 \mu \mathrm{M}$; Calbiochem, UK) was loaded into RBCs (5\% haematocrit) for $60 \mathrm{~min}$ at $37^{\circ} \mathrm{C}$ with added pyruvate $(5 \mathrm{mM})$ to prevent inhibition of glycolysis [33]. Extracellular chelator was removed by washing once with saline. Control RBCs without chelator were handled in the same way. FITClabelled annexin $\mathrm{V}$ was obtained from Becton-Dickinson (Oxford, UK) in aqueous stock solutions (final concentration $\left.0.3 \mu \mathrm{g} \cdot \mathrm{mL}^{-1}\right)$. The calmodulin inhibitor $N$-(6-aminohexyl)5-chloro-1-naphthalene sulphonamide (W-7) and the calcium fluorophore fluo-4-AM came from Invitrogen; all other reagents were obtained from Sigma (Poole, UK).

2.3. Control of $\mathrm{O}_{2}$ Tension, Measurement of PS Exposure and Intracellular $\mathrm{Ca}^{2+}$. Salines and $\mathrm{HbS}$ cell suspensions were first equilibrated with humidified air (oxygenated) or $\mathrm{N}_{2}$ (deoxygenated) in Eschweiler tonometers (Eschweiler, Kiel, Germany). They were then placed in 24-well plates $\left(10^{8}\right.$ cells $\cdot \mathrm{mL}^{-1}$, depth $3 \mathrm{~mm}$ ) at $37^{\circ} \mathrm{C}$ in humidified incubators flushed with room air or $1 \% \mathrm{O}_{2}$ (using a Galaxy-R oxygen incubator, RS Biotech, Irvine, UK) for 3-18 hours. After incubation, RBCs were treated with vanadate $(1 \mathrm{mM})$ to inhibit flippase activity. They were then immediately harvested, washed once, and resuspended at a concentration of $5 \times 10^{6}$ cells $\cdot \mathrm{mL}^{-1}$ in binding annexin buffer (composition in mM: $145 \mathrm{NaCl}, 2.5 \mathrm{CaCl}_{2}, 10$ HEPES, pH 7.4) and incubated for $15 \mathrm{~min}$ at room temperature with FITC-labelled annexin $\left(0.3 \mu \mathrm{g} \cdot \mathrm{mL}^{-1}\right)$. Unattached annexin was then removed by washing once followed by resuspension in 5-times the initial volume of ice-cold binding buffer, after which samples were placed on ice. Percentage of RBCs with PS exposed on their external membrane was then measured in the FL-1 channel of a fluorescence-activated flow cytometer (FACSCalibur, $\mathrm{BD})$, in which negative fluorescent gate was set using cells exposed to FITC-labelled annexin but in the absence of $\mathrm{Ca}^{2+}$ (which prevents annexin binding). PS exposure here refers to the percentage of RBCs which fluoresce more brightly than the negative gate. To alter intracellular $\left[\mathrm{Ca}^{2+}\right]$, RBCs at $1 \%$ Hct were exposed to the calcium ionophore bromoA23187 (1-6 $\mu \mathrm{M})$, vanadate ( $1 \mathrm{mM})$, EDTA $(2 \mathrm{mM})$, and different $\left[\mathrm{Ca}^{2+}\right]_{0} \mathrm{~s}$ for $30 \mathrm{~min}$ to achieve the requisite final $\left[\mathrm{Ca}^{2+}\right]_{o}[34]$. This was multiplied by the square of Donnan ratio, $r^{2}\left(\left[\mathrm{H}^{+}\right]_{i} /\left[\mathrm{H}^{+}\right]_{o}\right)^{2}=2.05[35,36]$, to calculate $\left[\mathrm{Ca}^{2+}\right]_{i}$. After $30 \mathrm{~min}$, RBCs were treated with $\mathrm{Co}^{2+}(0.4 \mathrm{mM}$, to block A23187) after which they were processed for annexinlabelling, as above. Annexin was used to label PS because it is important to compare findings with extensive reports in the literature using this PS marker (e.g., [8, 19, 37-39]). BromoA23187 (in preference to A23187 per se) was used because it does not fluoresce. These experiments were carried out in LK or HK saline, composition as above except for the addition of $0.15 \mathrm{mM} \mathrm{MgCl}_{2}$ to keep intracellular $\left[\mathrm{Mg}^{2+}\right]$ at physiological levels. Finally, to show $\mathrm{Ca}^{2+}$-loading of $\mathrm{RBCs}$, cells were loaded with fluo-4-AM ( $30 \mathrm{~min}$ at $37^{\circ} \mathrm{C}, 5 \mu \mathrm{M}$; then washed once) with fluo-4 fluorescence also then measured in the FITC channel by FACS.

2.4. Statistics. Unless otherwise stated, data are presented as means \pm S.E.M. for blood samples from $n$ patients. Statistical significance of any differences was tested using paired Student's $t$-test (with $P<.05$ taken as significant).

\section{Results}

3.1. The Effect of $\mathrm{Ca}^{2+}$ on PS Exposure. PS exposure in $\mathrm{HbS}$ cell samples taken from SCD patients and immediately labelled with FITC-annexin ranged from 0.4 to $16.0 \%$ with a mean of $2.3 \pm 0.5 \%(n=36)$. The effect of different $\left[\mathrm{Ca}^{2+}\right]_{o} \mathrm{~s}$ $(0.1,0.5,1.1,2$ and $5 \mathrm{mM})$ on the percentage of HbS cells showing PS exposure was then investigated. In oxygenated $\left(20 \% \mathrm{O}_{2}\right) \mathrm{HbS}$ cells, PS exposure was lower and although the extent of exposure was augmented when RBCs were incubated at higher $\left[\mathrm{Ca}^{2+}\right]_{o} \mathrm{~s}$, the effect was small and not significant (Figure 1). When cells were deoxygenated (1\% $\mathrm{O}_{2}$ ), PS exposure was always higher than that observed in oxygenated HbS cells. There was also a marked increase in 


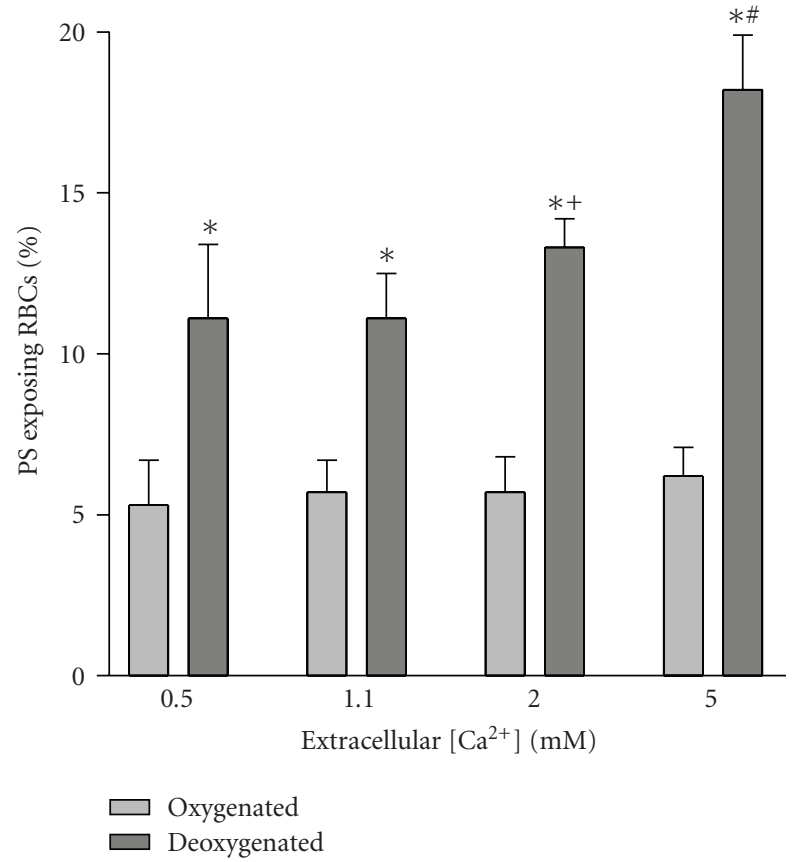

Figure 1: Effect of oxygen tension and extracellular $\mathrm{Ca}^{2+}$ on phosphatidylserine (PS) exposure in red blood cells (RBCs) from sickle cell patients. RBCs were incubated for 18 hours at four extracellular $\left[\mathrm{Ca}^{2+}\right]$ 's $(0.5,1.1,2.0$ and $5.0 \mathrm{mM})$ after which they were labelled with FITC-annexin (as described in Section 2). Histograms representing mean percentage of positive RBCs \pm S.E.M. for 5 different patients. ${ }^{*} P<.01$ deoxy compare to oxy; ${ }^{+} P<.05 \mathrm{cf} 0.5 \mathrm{mM} \mathrm{Ca}^{2+}$ deoxy; ${ }^{\#} P<.01 \mathrm{cf} 0.5 \mathrm{mM} \mathrm{Ca}^{2+}$ deoxy.

PS at the higher $\left[\mathrm{Ca}^{2+}\right]_{o} \mathrm{~s}$ (Figure 1). This effect was present within $30 \mathrm{~min}$, with longer incubation periods increasing the effect. To determine whether $\mathrm{Ca}^{2+}$ was acting extracellularly or intracellularly, $\mathrm{HbS}$ cells were loaded with the $\mathrm{Ca}^{2+}$ chelator MAPTAM prior to deoxygenation (Figure 2). Over a 3 hour period, MAPTAM decreased the percentage of positive HbS cells $(P<.01)$. This inhibitory effect did not persist over an 18 hour incubation, probably because the available cytoplasmic MAPTA becomes saturated with $\mathrm{Ca}^{2+}$.

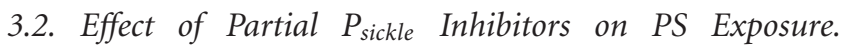
Although there are no specific inhibitors of $\mathrm{P}_{\text {sickle }}$, dipyridamole is partially effective [40]. When present during deoxygenation, dipyridamole $(50 \mu \mathrm{M})$ reduced PS exposure in deoxygenated $\mathrm{HbS}$ cells (Figure 2; $P<.01$ ), consistent with $\mathrm{Ca}^{2+}$ entry via $\mathrm{P}_{\text {sickle }}$ stimulating exposure. DIDS, although better known as a band 3 inhibitor, is also a partial $\mathrm{P}_{\text {sickle }}$ inhibitor [41]. Addition of DIDS $(50 \mu \mathrm{M})$, however, produced a marked increase in PS exposing RBCs with percentage of positive RBCs increasing several folds (Figure 2; $P<.01$ ). When DIDS was added to RBCs from normal HbAA individuals, PS exposure was also similarly increased: to $95.0 \pm 0.3 \%$ in oxygenated conditions, and to $98.7 \pm 0.1 \%$ in deoxygenated cells (both means \pm S.E.M., $n=$ $3)$. These findings suggest that annexin binding was caused

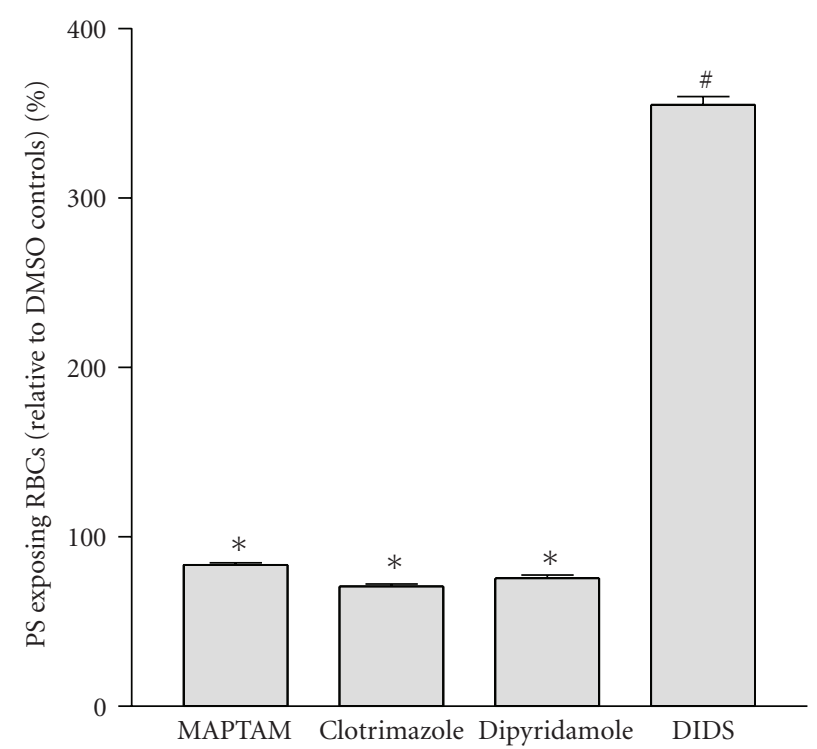

FIGURE 2: Effect of inhibitors on phosphatidylserine (PS) exposure in red blood cells (RBCs) from sickle cell patients. RBCs were incubated under deoxygenated conditions $\left(1 \% \mathrm{O}_{2}\right)$ for 3 hours $\left(5 \mathrm{mM}\right.$ extracellular $\left.\left[\mathrm{Ca}^{2+}\right]\right)$ after which they were labelled with FITC-annexin. Four conditions (all with $0.5 \%$ DMSO) are shown: MAPTAM-treated RBCs (loaded with $5 \mu \mathrm{M}$ MAPTAM prior to deoxygenation), clotrimazole $(10 \mu \mathrm{M})$, dipyridamole $(50 \mu \mathrm{M})$, and DIDS $(50 \mu \mathrm{M})$. Results are presented as percentage PS exposing RBCs relative to control RBCs exposed to $0.5 \%$ DMSO only. Histograms represent means \pm S.E.M. $(n=3) .{ }^{*} P<.01$ and ${ }^{\#} P<.0001$ cf DMSO controls.

by DIDS reacting with its target on the RBC membrane. $\mathrm{HbS}$ cells exposed to DIDS, but not subsequently treated with FITC-annexin, did not fluoresce (e.g., 0\% DIDS-treated without FITC-annexin of 50\% DIDS-treated with annexin), indicating that the high values were not due to fluorescence from DIDS itself.

3.3. PS Exposure and Red Cell Shrinkage. Elevated intracellular $\mathrm{Ca}^{2+}$ activates the Gardos channel and leads to $\mathrm{K}^{+}$ loss with $\mathrm{Cl}^{-}$following through separate $\mathrm{Cl}^{-}$channels [4]. PS exposure could therefore be secondary to the ensuing cell shrinkage [37]. To investigate this possibility, HbS cells were suspended in high $\mathrm{K}^{+}$-containing saline $(90 \mathrm{mM})$ to remove any gradient for $\mathrm{K}^{+}$efflux. The deoxygenationinduced increase in PS exposure was abolished (Figure 3), with values reduced to those observed in oxygenated samples $(P<.001$ deoxy LK cf oxy LK; N.S. deoxy HK cf oxy LK). An estimate of RBC size is provided by FACS forward scatter measurement. Forward scatter was $487 \pm 8$ (means \pm S.E.M., $n=3)$ in oxygenated LK saline, falling to $439 \pm 4$ in deoxygenated LK saline $(P<.005)$. In deoxygenated HK saline a value of $497 \pm 3$ was obtained (N.S. cf. oxygenated LK saline). PS exposure following deoxygenation in LK saline was therefore accompanied by cell shrinkage. This was not observed during deoxygenation in high $\mathrm{K}^{+}$saline. A second method of inhibiting the Gardos channel, treatment with 


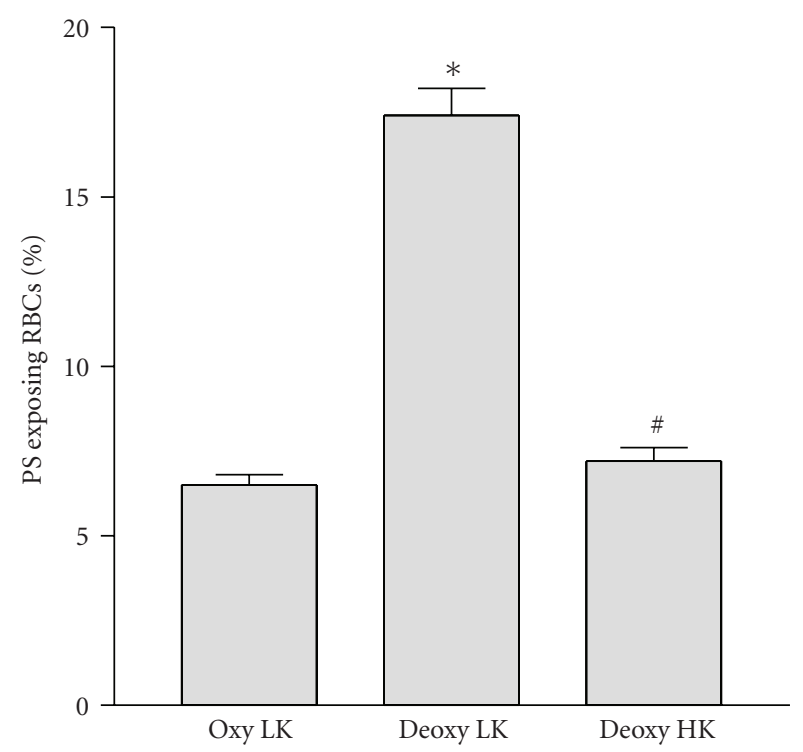

Figure 3: Effect of extracellular $\mathrm{K}^{+}$on phosphatidylserine (PS) exposure in red blood cells (RBCs) from sickle cell patients. RBCs were incubated for 18 hours with extracellular $\left[\mathrm{Ca}^{2+}\right]$ of $5 \mathrm{mM}$ under oxygenated $\left(20 \% \mathrm{O}_{2}\right)$ or deoxygenated $\left(1 \% \mathrm{O}_{2}\right)$ conditions in either low $\mathrm{K}^{+}$-containing (extracellular $\left[\mathrm{K}^{+}\right]$of $5 \mathrm{mM}$ ) saline or high $\mathrm{K}^{+}$-containing $\left(90 \mathrm{mM}\left[\mathrm{K}^{+}\right]\right)$saline. Histograms represent means \pm S.E.M. $(n=3) .{ }^{*} P<.001$ compare to LK oxy; ${ }^{\#}$ N.S. cf. LK oxy.

clotrimazole $(10 \mu \mathrm{M})$, was also tested. In this case, however, PS exposure was only partially prevented (Figure $2 ; P<.01$ ).

3.4. PS Exposure and Direct Manipulation of Intracellular $\left[\mathrm{Ca}^{2+}\right]$. Treatment of RBCs with the divalent cation ionophore bromo-A23187 was used to alter intracellular $\left[\mathrm{Ca}^{2+}\right]$ directly $[34,35]$. RBCs were initially treated with vanadate $(1 \mathrm{mM})$, to inhibit both the plasma membrane $\mathrm{Ca}^{2+}$ pump and also the flippase. Following $30 \mathrm{~min}$ incubation with bromo-A23187 to alter $\left[\mathrm{Ca}^{2+}\right]_{i}, \mathrm{Co}^{2+}(0.4 \mathrm{mM})$ was then added to block $\mathrm{Ca}^{2+}$ permeability via $\mathrm{A} 23187$ thereby keeping intracellular $\left[\mathrm{Ca}^{2+}\right]$ constant during annexin labelling (for which $2.5 \mathrm{mM}$ extracellular $\left[\mathrm{Ca}^{2+}\right]$ is required). Results are shown in Figure 4. PS exposure is elicited as $\left[\mathrm{Ca}^{2+}\right]_{i}$ increased above about $600 \mathrm{nM}$. A sigmoidal dependence of PS exposure with $\left[\mathrm{Ca}^{2+}\right]$ was then apparent with an $\mathrm{EC}_{50}$ of $1.31 \pm 0.84 \mu \mathrm{M}(n=6)$. Peak exposures varied from $16-46 \%$, mean $28 \pm 5(n=6)$ with a plateau reached at about $10 \mu \mathrm{M}$ and without further change at higher $\left[\mathrm{Ca}^{2+}\right]_{i} \mathrm{~s}$ ([Ca $\left.{ }^{2+}\right]$ s up to $600 \mu \mathrm{M}$ were tested).

3.5. Modulation of PS Exposure. In the preceding section, although high affinity $\mathrm{Ca}^{2+}$-induced scrambling was present, it was noticeable that nevertheless only a minority of all RBCs stained positively for PS using FITC-annexin-as is also found in many literature reports, for example, [39]. That $\mathrm{Ca}^{2+}$ loading was complete and homogeneous was first ascertained using intracellular fluo-4 (Figure 5). It is apparent that the majority of RBCs $(98 \pm 1 \%, n=3)$ were $\mathrm{Ca}^{2+}$-loaded. Uneven $\mathrm{Ca}^{2+}$ loading can therefore be

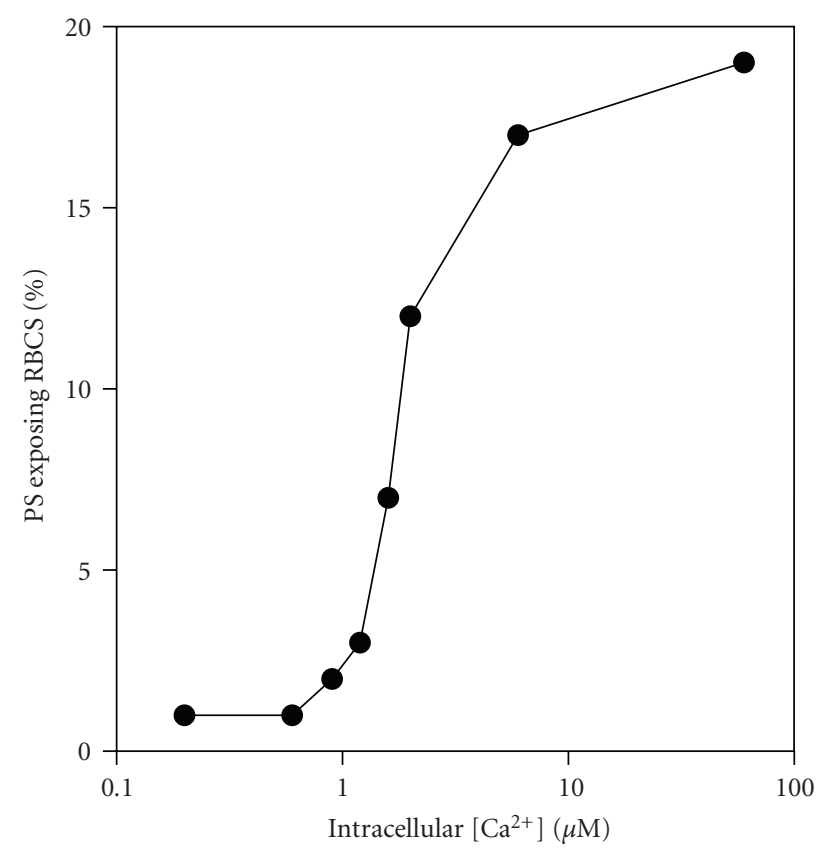

Figure 4: Effect of manipulation of intracellular $\mathrm{Ca}^{2+}$ on phosphatidylserine (PS) exposure in red blood cells (RBCs) from sickle cell patients. RBCs were first treated with vanadate $(1 \mathrm{mM})$ to inhibit the plasma membrane $\mathrm{Ca}^{2+}$ pump and also the aminophospholipid translocase (flippase) before addition of bromo-A23187 $\left(1.2 \mu \mathrm{M}, 1 \%\right.$ haematocrit) and requisite extracellular $\left[\mathrm{Ca}^{2+}\right] \mathrm{s}$ for $30 \mathrm{~min}$. They were then treated with $\mathrm{Co}^{2+}(0.4 \mathrm{mM})$ before labelling with FITC-annexin. Intracellular $\left[\mathrm{Ca}^{2+}\right]$ is calculated from extracellular $\left[\mathrm{Ca}^{2+}\right] \times r^{2}$, where $r^{2}$ was taken as 2.05 [36]. Results presented are from a single experiment representative of 5 others.

discounted. As $\mathrm{K}^{+}$has been reported to inhibit PS scrambling [42], the effect of 30 min incubation in LK saline compared to $\mathrm{HK}$ was determined in the presence of bromo-A23187 and different $\left[\mathrm{Ca}^{2+}\right]$. LK saline was found to increase the percentage of positive cells (Figure 6(a)), an effect again partially inhibited by clotrimazole $(10 \mu \mathrm{M})$ which, for example, reduced percentage of positive cells from $44 \%$ to $28 \%$ at $10 \mu \mathrm{M} \mathrm{Ca}^{2+}$. Finally, the effect of the calmodulin inhibitor W-7 was tested (Figure 6(b)). In this case, the percentage of positive RBCs increased. It was noticeable, however, that in all these manoeuvres, $\mathrm{Ca}^{2+}$ affinity was unaffected (Figure 6).

\section{Discussion}

Whilst it is well known that RBCs from SCD patients show elevated levels of PS exposure and that these are increased upon deoxygenation, the mechanism is not clear. The present results explore more fully that the role of $\mathrm{Ca}^{2+} . \mathrm{Ca}^{2+}$ concentrations required for scrambling is considerably lower than previously appreciated. The $\mathrm{Ca}^{2+}$ affinity of the scrambling process is not dissimilar to that associated with inhibition of flippase activity or activation of the $\mathrm{Ca}^{2+}$-activated $\mathrm{K}^{+}$ channel (Gardos channel). This important finding suggests coordination of these eryptotic events. Results also implicate a role for RBC shrinkage and shape change. 


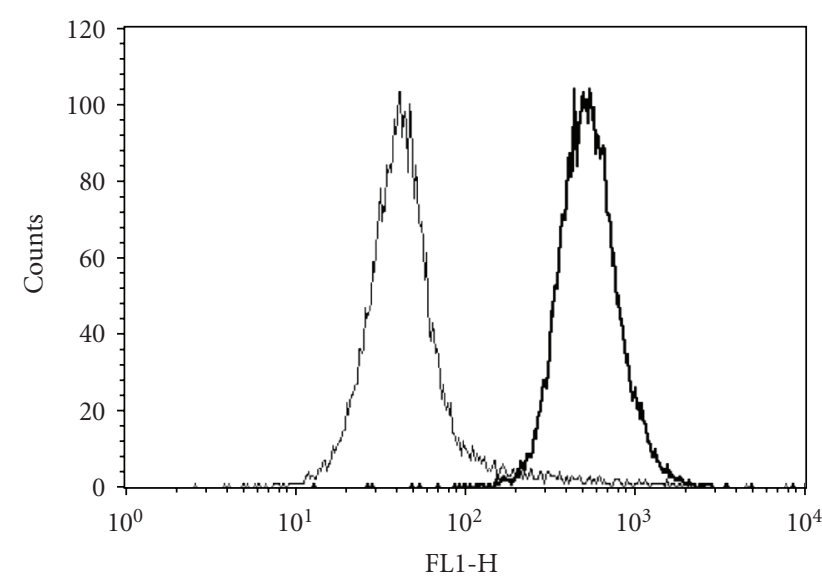

Figure 5: $\mathrm{Ca}^{2+}$ loading of red blood cells (RBCs) from sickle cell patients. RBCs were loaded with the $\mathrm{Ca}^{2+}$ fluorophore fluo-4 (see Methods). They were then incubated for $30 \mathrm{~min}$ in the absence (left-thin line) or presence (right — thick line) of bromo-A23187 at an extracellular $\left[\mathrm{Ca}^{2+}\right]$ of $1 \mu \mathrm{M}$. Results are presented as histogram of fluorescence of a single experiment representative of 3 .

4.1. Role of $\mathrm{Ca}^{2+}$ and $P_{\text {sickle }}$ on PS Exposure. Altering extracellular $\mathrm{Ca}^{2+}$ levels had little effect on PS exposure in oxygenated $\mathrm{HbS}$ cells. Under deoxygenated conditions, however, PS exposure increased with $\left[\mathrm{Ca}^{2+}\right]_{o}$. This effect was partially inhibited by dipyridamole [40] and by intracellular $\mathrm{Ca}^{2+}$ chelation with MAPTAM treatment [34]. These findings are consistent with $\mathrm{Ca}^{2+}$ entering via the deoxygenation-induced pathway $\mathrm{P}_{\text {sickle }}[4,27]$ and acting intracellularly. Intracellular $\mathrm{Ca}^{2+}$ can have several actions. First, it will activate the Gardos channel leading to RBC shrinkage [43]. Second, it may stimulate the $\mathrm{Ca}^{2+}$-dependent scramblase whilst inhibiting the ATP-dependent flippase [14]. Third, it may stimulate cysteine proteases [44]. Any of these events may lead to PS exposure [21]. Several manoeuvres were tested to separate these possibilities. The most effective way of inhibiting PS exposure was incubation in high $\mathrm{K}^{+}$saline. Removal of the electrochemical gradient for $\mathrm{K}^{+}$efflux abolished the deoxygenation-induced increase in PS exposure. The Gardos channel inhibitor clotrimazole also partially inhibited PS exposure. Findings are consistent with the hypothesis that activation of $\mathrm{P}_{\text {sickle }}$, by deoxygenation mediates $\mathrm{Ca}^{2+}$ entry, elevating $\left[\mathrm{Ca}^{2+}\right]_{i}$ which then promotes PS exposure by Gardos channel activation, loss of intracellular solutes, and red cell shrinkage. Importantly, high $\mathrm{K}^{+}$salines were effective over all incubation times (up to 18 hours). Shrinkage has been shown previously to stimulate PS exposure in both normal RBCs and HbS cells [37, 45] and would appear to be involved in deoxygenation-induced PS exposure in sickle cells.

4.2. $\mathrm{Ca}^{2+}$ Dependence of PS Exposure. A major aim of this work was to determine unequivocally the intracellular $\mathrm{Ca}^{2+}$ required to elicit $\mathrm{PS}$ exposure in $\mathrm{HbS}$ cells. This was investigated using RBCs loaded with different $\left[\mathrm{Ca}^{2+}\right] \mathrm{s}$ using bromo-A23187. RBCs were first treated with vanadate (to inhibit both the plasma membrane $\mathrm{Ca}^{2+}$ pump and

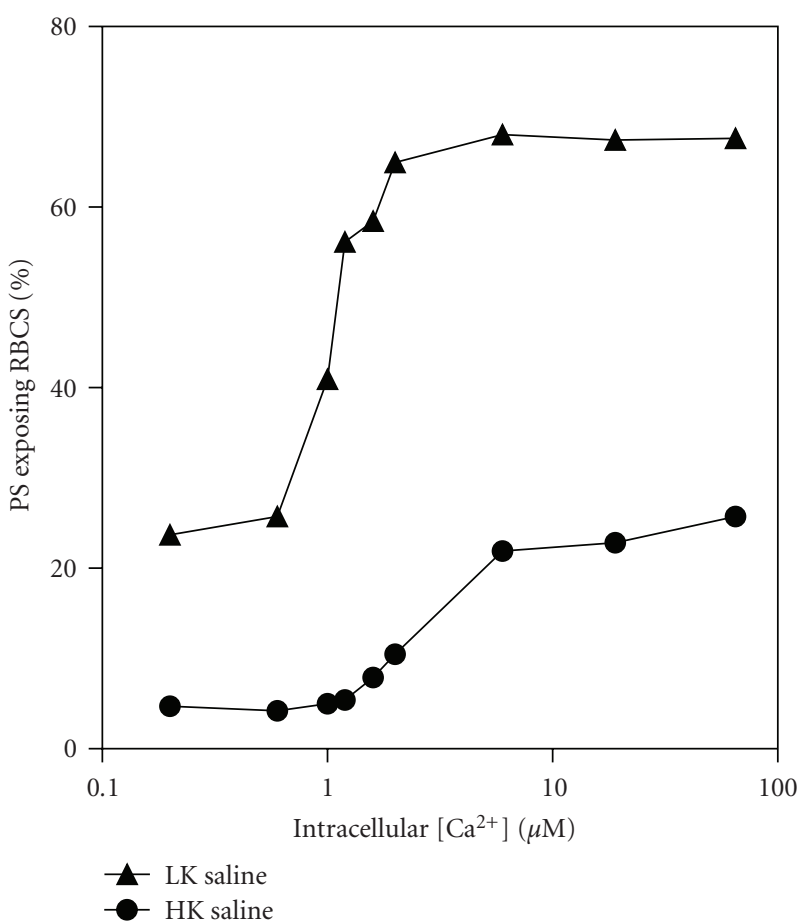

(a)

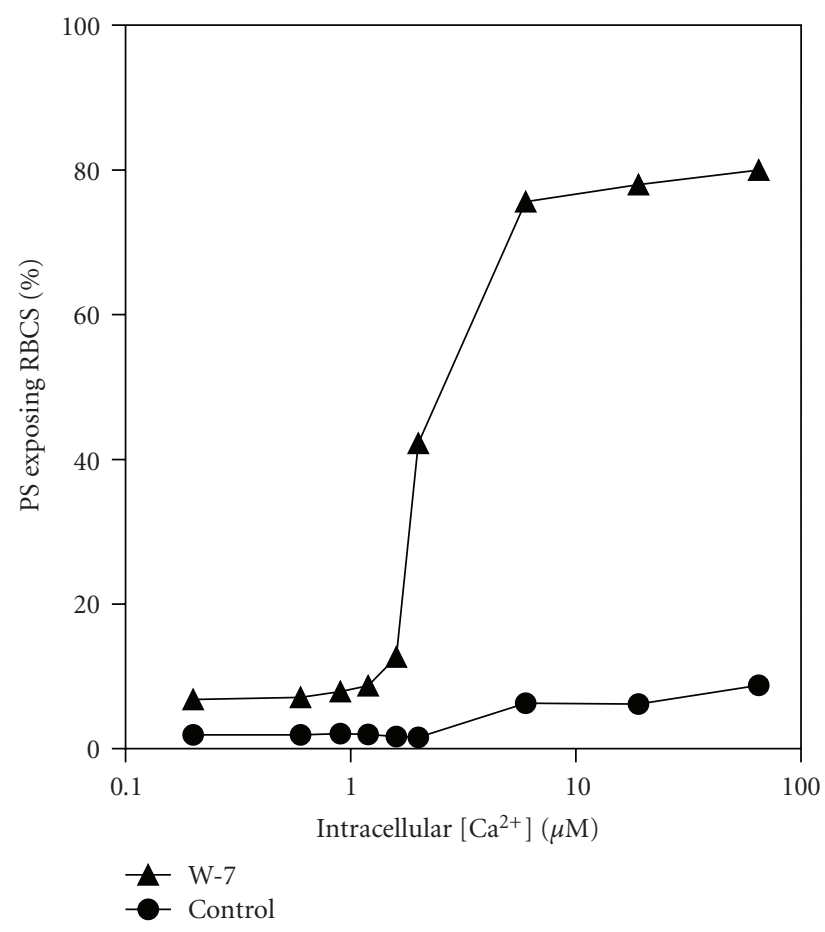

(b)

FIGURE 6: Effect of $\mathrm{K}^{+}$and calmodulin inhibition on $\mathrm{Ca}^{2+}$-induced exposure of phosphatidylserine (PS) in red blood cells (RBCs) from sickle cell patients. Experimental details were as described in the legend to Figure 4, except that in (a) where incubation was carried out in either high $\mathrm{K}^{+}-\left(\mathrm{HK}, \mathrm{K}^{+}=90 \mathrm{mM}\right)$ or low $\mathrm{K}^{+}$-containing saline (LK, $4 \mathrm{mM}$ ), and, in (b) where $\mathrm{HK}$ saline was used in the absence or presence of W-7 $(100 \mu \mathrm{M})$. Results are presented as single experiments representative of 3 others. 
the flippase) and subsequently with $\mathrm{Co}^{2+}$ (which blocks A23187 so that the relatively high $\left[\mathrm{Ca}^{2+}\right]$ required for annexin binding, $2.5 \mathrm{mM}$, could not gain access to the cytoplasm). Results showed that PS exposure was stimulated by micromolar $\mathrm{Ca}^{2+}$ concentrations with an $\mathrm{EC}_{50}$ of about $1.2 \mu \mathrm{M}$. This concentration is similar, though slightly higher, compared with that required for half-maximal activation of the Gardos channel activation $[46,47]$ and for inhibition of the flippase [26]. A similar high affinity for $\mathrm{Ca}^{2+}$ was also observed in RBCs incubated in LK saline indicating that high $\mathrm{K}^{+}$levels are not responsible for these observations. Calmodulin is known to interact with RBC cytoskeleton and influence PS exposure $[48,49]$. Incubation with the calmodulin antagonist W-7 again showed a similar high $\mathrm{Ca}^{2+}$ affinity for PS exposure. In this case, the percentage of positive cells was also increased so that the majority of RBCs became positive, showing that most RBCs are capable of PS scrambling at these low $\mathrm{Ca}^{2+}$ levels. Previously reported values for activation of the scramblase are considerably higher than those given here, with values of $25-100 \mu \mathrm{M}$ quoted [14, 32]. Previous measurements, however, were made largely on resealed RBC ghosts, inside-out vesicles, or purified PLSCR1 [30, 31, 50,51], which may not in fact represent the RBC scramblase [52]. These preparations will also necessarily lack much of the cytoplasmic contents which may result in reduction in $\mathrm{Ca}^{2+}$ affinity of the scrambling process. Furthermore, several previous reports were carried out in the presence of high concentrations of extracellular $\mathrm{Mg}^{2+}(1 \mathrm{mM})[20,30,50]$, which with the ionophore A23187 would set intracellular $\mathrm{Mg}^{2+}$ at over $2 \mathrm{mM}$, considerably in excess of the normal $\mathrm{RBC}\left[\mathrm{Mg}^{2+}\right]$ [53], and which might be expected to dampen any $\mathrm{Ca}^{2+}$ driven process. We speculate that having a similar $\mathrm{Ca}^{2+}$ level for Gardos channel activation, flippase inhibition and activation of scrambling would coordinate eryptotic events [21] and facilitate removal damaged RBCs in normal individuals, whilst in SCD patients, hyperactivity of these processes may contribute to disease pathogenesis.

\section{Authorship Contributions}

The paper was designed by J. S. Gibson and D. C. Rees and carried out by E. Weiss. E. Weiss and J. S. Gibson analysed the data. J. S. Gibson wrote the paper.

\section{Acknowledgment}

The authors thank the British Heart Foundation and the Medical Research Council Trust for financial support.

\section{References}

[1] M. H. Steinberg, "Sickle cell anemia, the first molecular disease: overview of molecular etiology, pathophysiology, and therapeutic approaches," TheScientificWorldJournal, vol. 8, pp. 1295-1324, 2008.

[2] L. Pauling, H. A. Itano, S. J. Singer, and I. C. Wells, "Sickle cell anemia, a molecular disease," Science, vol. 110, no. 2865, pp. 543-548, 1949.
[3] H. F. Bunn and B. G. Forget, Hemoglobin: Molecular, Genetic and Clinical Aspects, Saunders, Philadelphia, Pa, USA, 1986.

[4] V. L. Lew and R. M. Bookchin, "Ion transport pathology in the mechanism of sickle cell dehydration," Physiological Reviews, vol. 85, no. 1, pp. 179-200, 2005.

[5] R. P. Hebbel, W. T. Morgan, J. W. Eaton, and B. E. Hedlund, "Accelerated autoxidation and heme loss due to instability of sickle hemoglobin," Proceedings of the National Academy of Sciences of the United States of America, vol. 85, no. 1, pp. 237241, 1988.

[6] R. P. Hebbel, "Beyond hemoglobin polymerization: the red blood cell membrane and sickle disease pathophysiology," Blood, vol. 77, no. 2, pp. 214-237, 1991.

[7] J. F. Tait and D. Gibson, "Measurement of membrane phospholipid asymmetry in normal and sickle-cell erythrocytes by menas of annexin V binding," Journal of Laboratory and Clinical Medicine, vol. 123, no. 5, pp. 741-748, 1994.

[8] F. A. Kuypers, R. A. Lewis, M. Hua et al., "Detection of altered membrane phospholipid asymmetry in subpopulations of human red blood cells using fluorescently labeled annexin V," Blood, vol. 87, no. 3, pp. 1179-1187, 1996.

[9] K. De Jong, S. K. Larkin, L. A. Styles, R. M. Bookchin, and F. A. Kuypers, "Characterization of the phosphatidylserineexposing subpopulation of sickle cells," Blood, vol. 98, no. 3, pp. 860-867, 2001.

[10] B. N. Y. Setty, S. Kulkarni, and M. J. Stuart, "Role of erythrocyte phosphatidylserine in sickle red cell-endothelial adhesion," Blood, vol. 99, no. 5, pp. 1564-1571, 2002.

[11] R. P. Hebbel, M. A. B. Boogaerts, J. W. Eaton, and M. H. Steinberg, "Erythrocyte adherence to endothelium in sicklecell anemia. A possible determinant of disease severity," New England Journal of Medicine, vol. 302, no. 18, pp. 992-995, 1980.

[12] D. Chiu, B. Lubin, B. Roelofsen, and L. L. M. Van Deenen, "Sickled erythrocytes accelerate clotting in vitro: an effect of abnormal membrane lipid asymmetry," Blood, vol. 58, no. 2, pp. 398-401, 1981.

[13] B. N. Y. Setty and S. G. Betal, "Microvascular endothelial cells express a phosphatidylserine receptor: a functionally active receptor for phosphatidylserine-positive erythrocytes," Blood, vol. 111, no. 2, pp. 905-914, 2008.

[14] C. W. M. Haest, "Distribution and movement of membrane lipids," in Red Cell Membrane Transport in Health and Disease, I. Bernhardt and J. C. Ellory, Eds., pp. 1-25, Springer, Berlin, Germany, 2003.

[15] B. L. Wood, D. F. Gibson, and J. F. Tait, "Increased erythrocyte phosphatidylserine exposure in sickle cell disease: flowcytometric measurement and clinical associations," Blood, vol. 88, no. 5, pp. 1873-1880, 1996.

[16] F. A. Kuypers, "Phospholipid asymmetry in health and disease," Current Opinion in Hematology, vol. 5, no. 2, pp. 122$131,1998$.

[17] L. A. Barber, M. B. Palascak, C. H. Joiner, and R. S. Franco, "Aminophospholipid translocase and phospholipid scramblase activities in sickle erythrocyte subpopulations," British Journal of Haematology, vol. 146, no. 4, pp. 447-455, 2009.

[18] P. F. Devaux and A. Zachowski, "Maintenance and consequences of membrane phospholipid asymmetry," Chemistry and Physics of Lipids, vol. 73, no. 1-2, pp. 107-120, 1994.

[19] K. De Jong, D. Geldwerth, and F. A. Kuypers, "Oxidative damage does not alter membrane phospholipid asymmetry in human erythrocytes," Biochemistry, vol. 36, no. 22, pp. 67686776, 1997. 
[20] P. Williamson, A. Kulick, A. Zachowski, R. A. Schlegel, and P. F. Devaux, " $\mathrm{Ca}^{2+}$ induces transbilayer redistribution of all major phospholipids in human erythrocytes," Biochemistry, vol. 31, no. 27, pp. 6355-6360, 1992.

[21] F. Lang, K. S. Lang, P. A. Lang, S. M. Huber, and T. Wieder, "Mechanisms and significance of eryptosis," Antioxidants and Redox Signaling, vol. 8, no. 7-8, pp. 1183-1192, 2006.

[22] D. Chiu, B. Lubin, and S. B. Shohet, "Erythrocyte membrane lipid reorganization during the sickling process," British Journal of Haematology, vol. 41, no. 2, pp. 223-234, 1979.

[23] B. Lubin, D. Chiu, and J. Bastacky, "Abnormalities in membrane phospholipid organization in sickled erythrocytes," Journal of Clinical Investigation, vol. 67, no. 6, pp. 1643-1649, 1981.

[24] P. F. H. Franck, E. M. Bevers, B. H. Lubin, et al., "Uncoupling of the membrane skeleton from the lipid bilayer. The cause of accelerated phospholipid flip-flop leading to an enhanced procoagulant activity of sickled cells," Journal of Clinical Investigation, vol. 75, no. 1, pp. 183-190, 1985.

[25] E. Middelkoop, B. H. Lubin, E. M. Bevers et al., "Studies on sickled erythrocytes provide evidence that the asymmetric distribution of phosphatidylserine in the red cell membrane is maintained by both ATP-dependent translocation and interaction with membrane skeletal proteins," Biochimica et Biophysica Acta, vol. 937, no. 2, pp. 281-288, 1988.

[26] M. Bitbol, P. Fellmann, A. Zachowski, and P. F. Devaux, "Ion regulation of phosphatidylserine and phosphatidylethanolamine outside-inside translocation in human erythrocytes," Biochimica et Biophysica Acta, vol. 904, no. 2, pp. 268-282, 1987.

[27] C. H. Joiner, "Cation transport and volume regulation in sickle red blood cells," American Journal of Physiology, vol. 264, no. 2, pp. C251-C270, 1993.

[28] M. D. Rhoda, M. Apovo, Y. Beuzard, and F. Giraud, "Ca ${ }^{2+}$ permeability in deoxygenated sickle cells," Blood, vol. 75, no. 12, pp. 2453-2458, 1990.

[29] Z. Etzion, T. Tiffert, R. M. Bookchin, and V. L. Lew, "Effects of deoxygenation on active and passive $\mathrm{Ca}^{2+}$ transport and on the cytoplasmic $\mathrm{Ca}^{2+}$ levels of sickle cell anemia red cells," Journal of Clinical Investigation, vol. 92, no. 5, pp. 2489-2498, 1993.

[30] B. Verhoven, R. A. Schlegel, and P. Williamson, "Rapid loss and restoration of lipid asymmetry by different pathways in resealed erythrocyte ghosts," Biochimica et Biophysica Acta, vol. 1104, no. 1, pp. 15-23, 1992.

[31] F. Bassé, J. G. Stout, P. J. Sims, and T. Wiedmer, "Isolation of an erythrocyte membrane protein that mediates $\mathrm{Ca}^{2+}$-dependent transbilayer movement of phospholipid," Journal of Biological Chemistry, vol. 271, no. 29, pp. 17205-17210, 1996.

[32] D. Kamp, T. Sieberg, and C. W. M. Haest, "Inhibition and stimulation of phospholipid scrambling activity. Consequences for lipid asymmetry, echinocytosis, and microvesiculation of erythrocytes," Biochemistry, vol. 40, no. 31, pp. 9438-9446, 2001.

[33] J. Garcia-Sancho, "Pyruvate prevents the ATP depletion caused by formaldehyde or calcium-chelator esters in the human red cell," Biochimica et Biophysica Acta, vol. 813, no. 1, pp. 148-150, 1985.

[34] T. Tiffert, Z. Etzion, R. M. Bookchin, and V. L. Lew, "Effects of deoxygenation on active and passive $\mathrm{Ca}^{2+}$ transport and cytoplasmic $\mathrm{Ca}^{2+}$ buffering in normal human red cells," Journal of Physiology, vol. 464, pp. 529-544, 1993.
[35] P. Flatman and V. L. Lew, "Use of ionophore A23187 to measure and to control free and bound cytoplasmic $\mathrm{Mg}$ in intact red cells," Nature, vol. 267, no. 5609, pp. 360-362, 1977.

[36] M. C. Muzyamba, E. H. Campbell, and J. S. Gibson, "Effect of intracellular magnesium and oxygen tension on $\mathrm{K}^{+}-\mathrm{Cl}^{-}$ cotransport in normal and sickle human red cells," Cellular Physiology and Biochemistry, vol. 17, no. 3-4, pp. 121-128, 2006.

[37] K. Lang, B. Roll, S. Myssina et al., "Enhanced erythrocyte apoptosis in sickle cell anemia, thalassemia and glucose-6phosphate dehydrogenase deficiency," Cellular Physiology and Biochemistry, vol. 12, no. 5-6, pp. 365-372, 2002.

[38] Z. Yasin, S. Witting, M. B. Palascak, C. H. Joiner, D. L. Rucknagel, and R. S. Franco, "Phosphatidylserine externalization in sickle red blood cells: associations with cell age, density, and hemoglobin F," Blood, vol. 102, no. 1, pp. 365-370, 2003.

[39] K. de Jong and F. A. Kuypers, "Sulphydryl modifications alter scramblase activity in murine sickle cell disease," British Journal of Haematology, vol. 133, no. 4, pp. 427-432, 2006.

[40] C. H. Joiner, M. Jiang, W. J. Claussen, N. J. Roszell, Z. Yasin, and R. S. Franco, "Dipyridamole inhibits sickling-induced cation fluxes in sickle red blood cells," Blood, vol. 97, no. 12, pp. 3976-3983, 2001.

[41] C. H. Joiner, "Deoxygenation-induced cation fluxes in sickle cells: II. Inhibition by stilbene disulfonates," Blood, vol. 76, no. 1, pp. 212-220, 1990.

[42] J. L. N. Wolfs, P. Comfurius, O. Bekers et al., "Direct inhibition of phospholipid scrambling activity in erythrocytes by potassium ions," Cellular and Molecular Life Sciences, vol. 66, no. 2, pp. 314-323, 2009.

[43] G. Gárdos, "The function of calcium in the potassium permeability of human erythrocytes," Biochimica et Biophysica Acta, vol. 30, no. 3, pp. 653-654, 1958.

[44] D. R. Anderson, J. L. Davis, and K. L. Carraway, "Calciumpromoted changes of the human erythrocyte membrane. Involvement of spectrin, transglutaminase, and a membranebound protease," Journal of Biological Chemistry, vol. 252, no. 19, pp. 6617-6623, 1977.

[45] K. S. Lang, S. Myssina, V. Brand et al., "Involvement of ceramide in hyperosmotic shock-induced death of erythrocytes," Cell Death and Differentiation, vol. 11, no. 2, pp. 231-243, 2004.

[46] T. Tiffert, J. L. Spivak, and V. L. Lew, "Magnitude of calcium influx required to induce dehydration of normal human red cells," Biochimica et Biophysica Acta, vol. 943, no. 2, pp. 157-165, 1988.

[47] P. Bennekou and P. Christophersen, "Ion channels," in Red Cell Membrane in Health and Disease, I. Bernhardt and J. C. Ellory, Eds., pp. 139-152, Springer, Berlin, Germany, 2003.

[48] M. Strömqvist, Å. Berglund, V. P. Shanbhag, and L. Backman, "Influence of calmodulin on the human red cell membrane skeleton," Biochemistry, vol. 27, no. 4, pp. 1104-1110, 1988.

[49] Z. Wang, S. Li, Q. Shi, R. Yan, G. Liu, and K. Dai, "Calmodulin antagonists induce platelet apoptosis," Thrombosis Research, vol. 125, no. 4, pp. 340-350, 2010.

[50] L. A. Woon, J. W. Holland, E. P. W. Kable, and B. D. Roufogalis, " $\mathrm{Ca}^{2+}$ sensitivity of phospholipid scrambling in human red cell ghosts," Cell Calcium, vol. 25, no. 4, pp. 313-320, 1999.

[51] J. G. Stout, Q. Zhou, T. Wiedmer, and P. J. Sims, "Change in conformation of plasma membrane phospholipid scramblase induced by occupancy of its $\mathrm{Ca}^{2+}$ binding site," Biochemistry, vol. 37, no. 42, pp. 14860-14866, 1998. 
[52] Q. Zhou, J. Zhao, T. Wiedmer, and P. J. Sims, "Normal hemostasis but defective hematopoietic response to growth factors in mice deficient in phospholipid scramblase 1," Blood, vol. 99, no. 11, pp. 4030-4038, 2002.

[53] P. W. Flatman, "The effect of buffer composition and deoxygenation on the concentration of ionized magnesium inside human red blood cells," Journal of Physiology, vol. 300, pp. 19-30, 1980. 


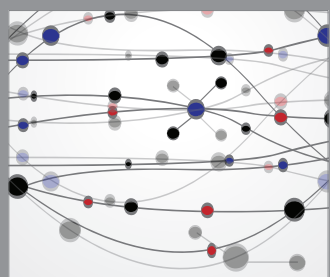

The Scientific World Journal
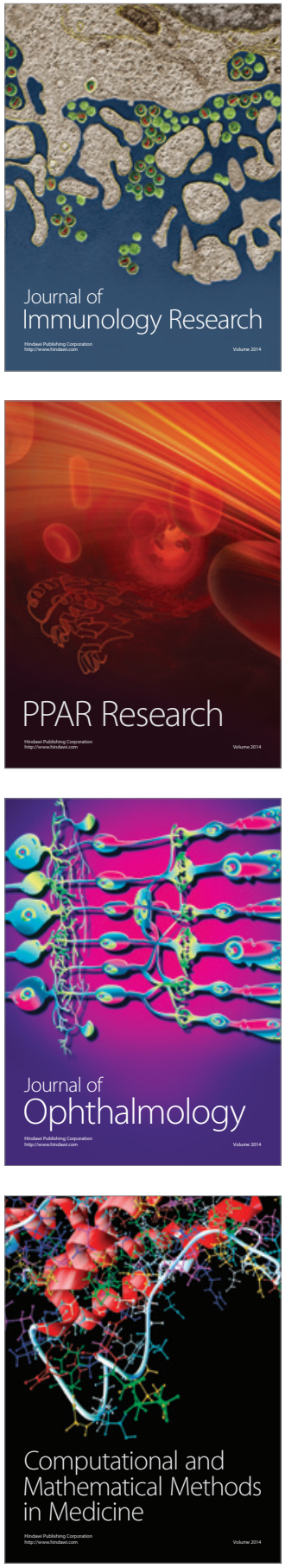

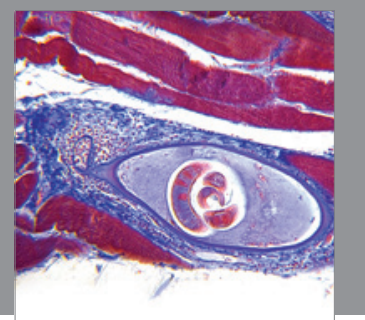

Gastroenterology

Research and Practice
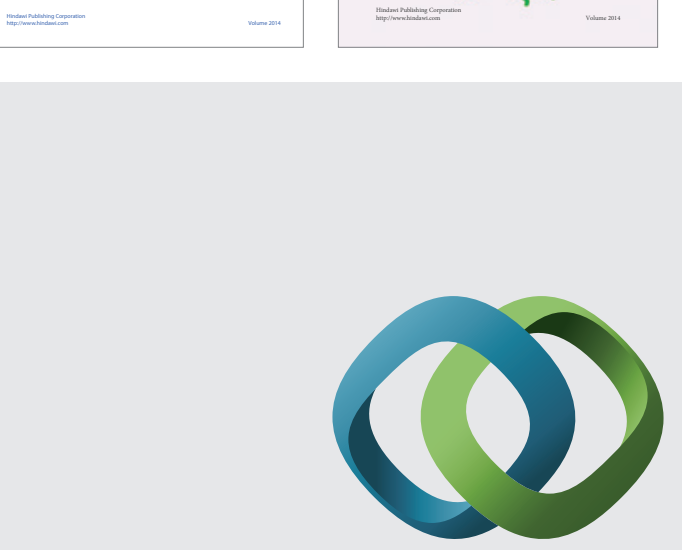

\section{Hindawi}

Submit your manuscripts at

http://www.hindawi.com
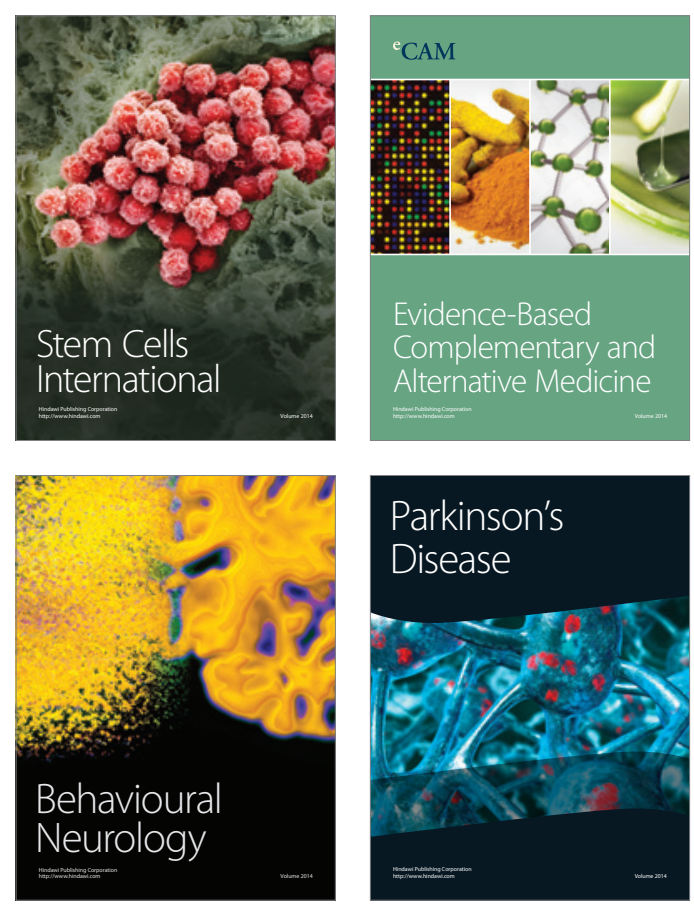

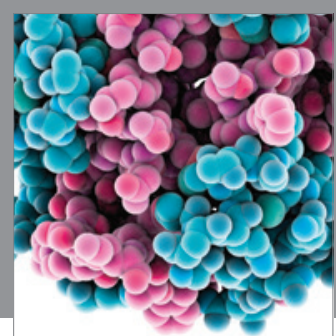

Journal of
Diabetes Research

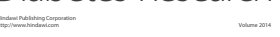

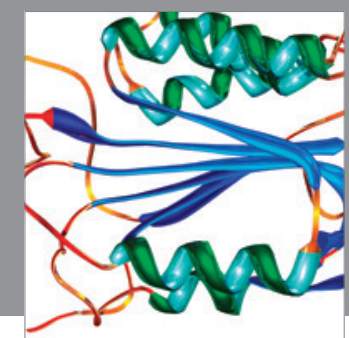

Disease Markers
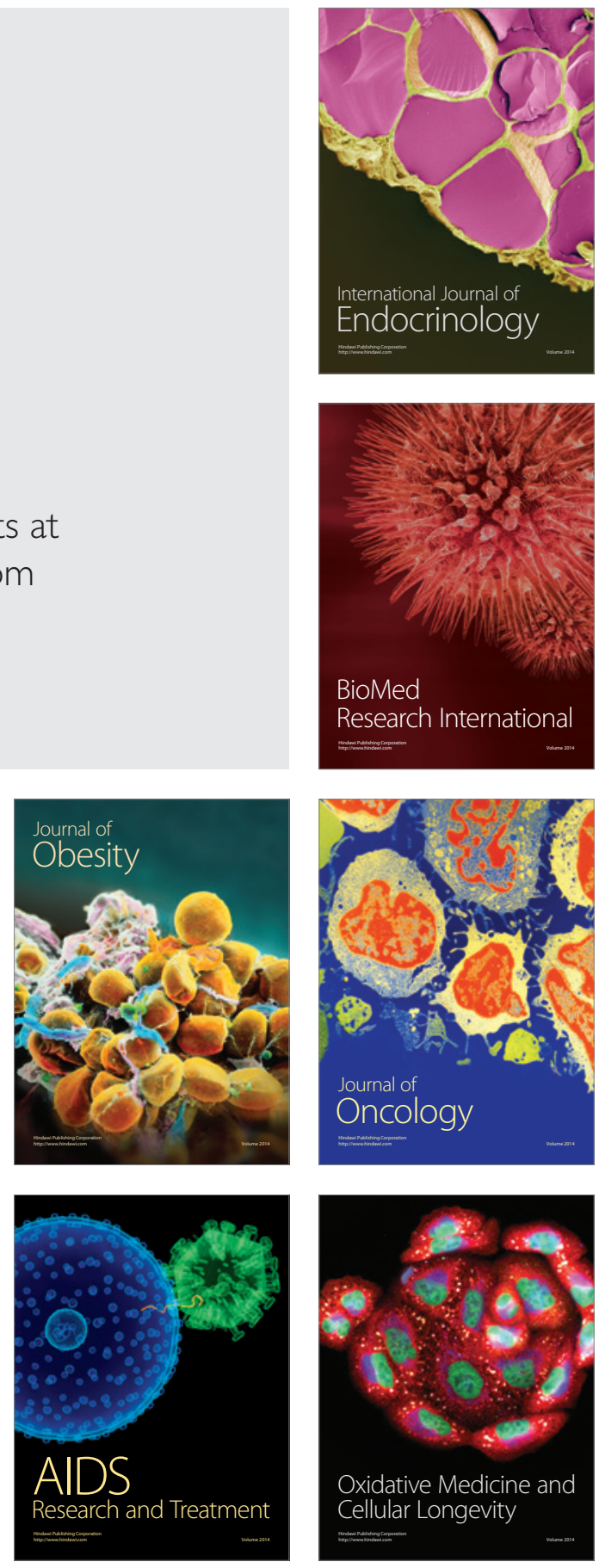